\title{
논문 2
}

[2013-6-PV-002]

\section{$1 \mathrm{~km}$ 해상도 태양-기상자원지도 기반의 초고해상도 태양 에너지 분석}

지준범*, 조일성, 이채연, 최영진, 김규랑, 이규태**

\section{Analysis of Very High Resolution Solar Energy Based on Solar-Meteorological Resources Map with $1 \mathrm{~km}$ Spatial Resolution}

JoonBum Jee*, Ilsung Zo, Chaeyon Lee, Youngjean Choi, Kyurang Kim and KyuTae Lee**

Abstract The solar energy are an infinite source of energy and a clean energy without secondary pollution. The global solar energy reaching the earth's surface can be calculated easily according to the change of latitude, altitude, and sloped surface depending on the amount of the actual state of the atmosphere and clouds. The high-resolution solar-meteorological resource map with $1 \mathrm{~km}$ resolution was developed in 2011 based on GWNU (Gangneung-Wonju National University) solar radiation model with complex terrain. The very high resolution solar energy map can be calculated and analyzed in Seoul and Eunpyung with topological effect using by $1 \mathrm{~km}$ solar-meteorological resources map, respectively. Seoul DEM (Digital Elevation Model) have $10 \mathrm{~m}$ resolution from NGII (National Geographic Information Institute) and Eunpyeong new town DSM (Digital Surface Model) have $1 \mathrm{~m}$ spatial resolution from lidar observations. The solar energy have small differences according to the local mountainous terrain and residential area. The maximum bias have up to $20 \%$ and $16 \%$ in Seoul and Eunpyung new town, respectively. Small differences are that limited area with resolutions. As a result, the solar energy can calculate precisely using solar radiation model with topological effect by digital elevation data and its results can be used as the basis data for the photovoltaic and solar thermal generation.

Key words

Solar-Meteorological Resources Map(태양-기상자원지도), Solar Radiation(태양복사), Solar Energy(태양 에너지), DEM(Digital Elevation Model; 수치표고모델), DSM(Digital Surface Model; 수치지표모델)

(접수일 2013. 5. 24, 수정일 2013. 6. 14, 게재확정일 2013. 6. 14)

* (재)기상기술개발원 차세대도시농림융합기상사업단 (Weather Information Service Engine, Center for ATmospheric sciences and Earthquake Research(CATER))

E-mail : rokmcjjb717@gmail.com —Tel : (070)4617-3764_ Fax : (02)6922-2930

** 강릉원주대학교 대기환경과학과 (Department of Atmospheric and Environmental Sciences, Gangneung-Wonju National University) E-mail : ktlee@gwnu.ac.kr $\square$ Tel : (033)640-2324 — Fax : (033)640-2324 


\section{Nomenclature}

$I, \quad B$ : solar energy $\left(W / m^{2}\right)$ on horizontal and slope

$\theta \quad$ : solar zenith angle $\left(^{\circ}\right)$

$\beta \quad$ : slope ( $\left.{ }^{\circ}\right)$

$\phi \quad: \operatorname{aspect}\left({ }^{\circ}\right)$

$\phi_{0} \quad$ : azimuth angle ( $\left.{ }^{\circ}\right)$

$H \quad$ : shading angle $\left({ }^{\circ}\right)$

$V \quad:$ sky-view factor

$x, y:$ index of $x, y$ direction

$z \quad$ : elevation $(m)$

\section{Subscript}

glo, dir, dif : component of solar energy

$i, 1,2,3,4,5,6,7,8,9$ : index of grid point

\section{1. 서 론}

태양 에너지는 지구에 끊임없이 도달되는 무한의 에너지원 이며 이차적 오염이 없는 깨끗한 청정에너지이다. 전지구의 지표면에 도달되는 태양 에너지는 위도와 지형고도 등의 변 화에 따라 맑은 상태에서는 쉽게 계산될 수 있으나 실제 대기 의 오염정도와 구름량의 변화에 따라 그 변화가 심하기 때문 에 계산의 정확도는 그리 높지 않다(Giuseppe and Tompkins, 2005 ; 정연진 등, 2011 ; 김의환 등, 2011) ${ }^{(1,2,3)}$. 또한 지상관 측에 의한 태양 에너지 분포는 실제 기상 및 지표면 상태 그 리고 대기의 상태변화와는 다소 다르게 단순화되어 나타난 다. 최근 서울 지역은 도시화와 기후변화 등의 원인으로 연무 가 자주 발생되며 봄철 중국으로 부터 황사의 영향 등으로 다 른 지역과 비교하여 비교적 오염의 정도가 높게 나타난다(신 은상 등, 2001; 박승명 등, 2012) $)^{(4,5)}$. 또한 지표면을 덮은 인 공구조물과 건물 등은 다양한 형태(산란, 반사)로 태양 에너 지의 관측을 어렵게 한다. 국립 기상연구소는 2010 년 정지기 상 위성자료를 기반으로 $1 \mathrm{~km}$ 해상도 태양-기상자원지도를 발표하였으며 2011년에는 1년간의 자료를 추가로 분석하여 이를 개선하였다(국립기상연구소, 2011; 지준범 등, 2012) ${ }^{(6,7)}$. $1 \mathrm{~km}$ 해상도의 태양-기상자원지도는 지준범 등 $(2011)^{(8)}$, 이
규태 등 $(2011)^{(9)}$, 조일성 등 $(2010)^{(10)}$ 의 GWNU 단층태양복사 모델을 이용하여 정지기상위성으로부터 산출된 구름량을 기 반으로 계산되었으며 한반도의 $1 \mathrm{~km}$ 해상도 지형고도 자료를 이용하여 지형효과를 고려하였다. 최근 NASA는 고해상도 SRTM (Shuttle Radar Topography Mission) 지형자료(3초 (90m) 해상도), 국토지리정보원의 고해상도(1초 $(30 \mathrm{~m})$ 해상도) 수 치고도(DEM; Digital Elevation Model)자료 및 라이다 기반 의 초고해상도 $(10 \mathrm{~m}$ 해상도) 자료를 제공하고 있으며 수도권 일부지역은 라이더 항공관측자료를 이용하여 $1 \mathrm{~m}$ 해상도의 $\mathrm{DSM}$ (Digital Surface Model) 자료를 제공하고 있다(이채연 등, 2012 $)^{(11)}$. 초고해상도의 DSM자료는 지표면의 식생뿐만 아니라 지표면의 인공구조물인 건물들의 고도가 그대로 반영 되어 나타나며 지형에 따른 바람길 연구 또는 기후효과연구 의 기초자료가 된다.

이 연구에서는 $1 \mathrm{~km}$ 해상도의 태양-기상자원지도의 계산 결과를 이용하여 $10 \mathrm{~m}$ 해상도의 서울 수치고도자료와 $1 \mathrm{~m}$ 해 상의 은평구 수치지면자료를 이용하여 태양 에너지의 잠재량 을 계산하였다. 지형자료에 기반된 간단한 알고리즘이 적용 되었으나 고해상도 지형자료에 기반된 월별 또는 연누적 계산 결과를 비교하여 태양 에너지의 분포와 특성을 분석하였다.

\section{2. 연구자료 및 방법}

\section{1 지형 효과}

지표면에 도달하는 태양 에너지는 태양복사모델을 이용하 여 계산된다. 에너지의 진행특성에 따라 직달 성분(direct radiation, $I_{d i r}$ )과 산란 성분(diffuse radiation, $I_{d i f}$ )으로 나 뉘어 계산되고 태양 천정각(solar zenith angle, $\theta$ )을 이용하 여 수평면에 도달되는 전천 태양 에너지(global radiation, $\left.I_{g l o}\right)$ 으로 계산된다.

$$
I_{g l o}=I_{d i r} \cos \theta+I_{d i f}
$$

그러나 태양 에너지는 수평면뿐만 아니라 경사면에도 도달 되기 때문에 지형고도로부터 계산되는 경사방향과 경사각 그 리고 천공률이 이용된다. 수치고도 자료가 $\mathrm{x}, \mathrm{y}$ 방향으로 등 


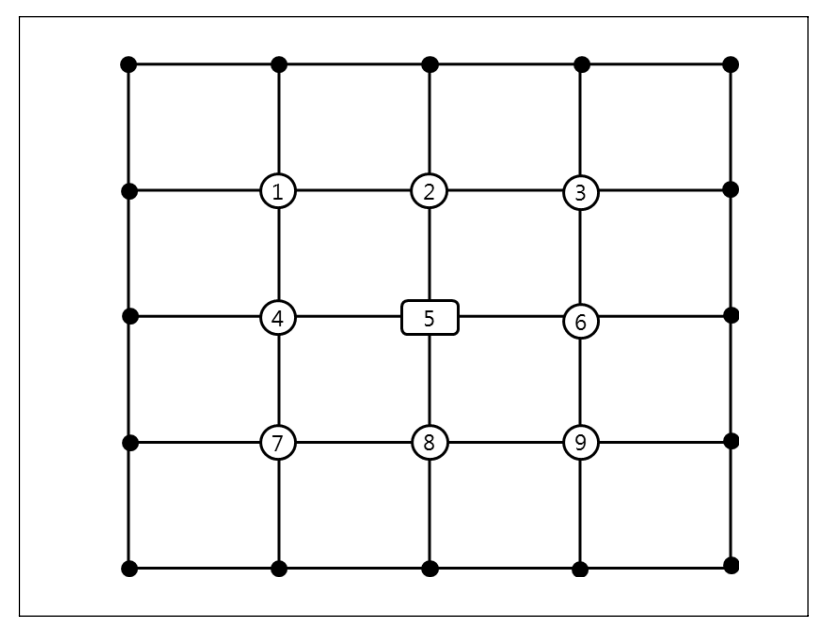

Fig. 1 Schematic diagram of DEM grid

거리에 위치한다고 가정할 때 중심 격자점에서의 경사각 (slope; $\beta$ )과 경사방향(aspect; $\phi$ )은 다음 식으로 계산된다 (Lai et al, 2009; Zhou and Liu, 2004; Horn, 1981) $)^{(12,13,14)}$

$$
\begin{aligned}
& \beta=\tan ^{-1} \sqrt{\left(\frac{d z}{d x}\right)^{2}+\left(\frac{d z}{d y}\right)^{2}} \\
& \phi=270^{\circ}+\tan ^{-1}\left(\frac{-\frac{d z}{d x}}{\frac{d z}{d y}}\right)-90^{\circ} \frac{\frac{d z}{d y}}{\left|\frac{d z}{d y}\right|}
\end{aligned}
$$

여기서 $\frac{d z}{d x}$ 와 $\frac{d z}{d y}$ 는 동서방향 및 남북방향의 고도의 편차 로서 Fig. 1 의 5 격자의 계산은 다음과 같이 계산되며 아래 첨자는 각각의 격자점을 의미한다.

$$
\begin{aligned}
& \frac{d z}{d x}=\frac{\left(z_{3}-z_{1}\right)+2\left(z_{6}-z_{4}\right)+\left(z_{9}-z_{7}\right)}{8 d x} \\
& \frac{d z}{d y}=\frac{\left(z_{7}-z_{1}\right)+2\left(z_{8}-z_{2}\right)+\left(z_{9}-z_{3}\right)}{8 d y}
\end{aligned}
$$

지형효과가 포함된 직달 성분의 태양 에너지는 식 (6)과 같다.

$$
B_{d i r}=\frac{I_{d i r}}{\cos \beta} \frac{\cos \theta_{T}}{\cos \theta}
$$

여기서 $I_{d i r}$ 는 수평면의 직달 태양 에너지를 의미하며 $\beta$ 는 경사각(slope angle)을 의미한다. $\theta_{T}$ 는 태양 천정각과 계산 지점 경사면의 연직선 사이의 각으로서 식 (7)과 같이 계산된다.

$$
\cos \theta_{T}=\sin \beta \sin \theta \cos \left(\phi_{0}-\phi\right)+\cos \beta \cos \theta
$$

여기서 $\phi_{0}$ 와 $\phi$ 는 각각 방위각(azimuth angle)과 계산 지 점의 경사면 방위각(aspect angle)을 의미한다(Kondratyev, $1969)^{(15)}$. 또한 계산 지점(거리는 $x_{0}$ 이고 고도는 $z_{0}$ )으로부터 $\phi$ 방향으로 거리 $x_{i}$ 만큼 떨어져 있는 태양 차폐 지형의 고도 가 $z_{i}$ 일 경우 직달 태양광의 차폐각(shading angle, $\left.H_{i}(\phi)\right)$ 은 다음 식과 같이 나타낸다.

$$
H_{i}(\phi)=\tan ^{-1}\left(\frac{x_{i}-x_{0}}{z_{i}-z_{0}}\right)
$$

식 (7)과 (8)에서 $\theta_{T}>90^{\circ}$ 일 경우는 계산 지점의 지형 자 체에 의하여 직달 태양광이 차폐되는 것(self-shading)을 의 미하고 $\theta_{0}>H(\phi)$ 는 계산 지점에서 멀리 떨어진 지형이 직 달 태양광을 차폐하는 것(shading)이다.

다음으로 태양광의 산란 성분에 대한 지형 효과는 다음과 같이 계산된다.

$$
B_{d i f}=V \frac{I_{d i f}}{\cos \beta}
$$

여기서 $I_{d i f}$ 는 수평면의 산란 태양 에너지이고 $V$ 는 천공률 (sky-view factor)로써 주변 지형들이 산란 태양 에너지 계 산에 미치는 영향을 0 에서 1 사이의 값으로 나타낸 것이며 다 음 식과 같이 계산된다.

$$
\begin{aligned}
V=\frac{1}{2 \pi} & {\left[\int_{\phi-\phi_{n}=\pi / 2}^{3 \pi / 2} \sin ^{2} \gamma_{1} d\left(\phi_{0}-\phi\right)\right.} \\
& \left.+\int_{\phi-\phi_{n}=-\pi / 2}^{\pi / 2} \sin ^{2} \gamma_{2} d\left(\phi_{0}-\phi\right)\right]
\end{aligned}
$$

즉 식 (10)의 천공률은 관측지점이 전 방향에 대하여 산란 태양 에너지의 차폐가 발생되지 않을 경우 1 이고 차폐 발생 정도가 클수록 0 에 가깝게 되며 이 식에서 $\gamma_{1}$ 과 $\gamma_{2}$ 는 다음과 같이 계산된다. 


$$
\begin{aligned}
\gamma_{1} & =\operatorname{Min}\left[H+\lambda, \frac{\pi}{2}\right] \\
\gamma_{2} & =\operatorname{Max}[H+\lambda, 0]
\end{aligned}
$$

여기서 $\mathrm{H}$ 는 식 (8)에서 계산되는 그림자 각으로 계산 지점 의 방위각에 대한 차폐각을 의미하며 $\lambda$ 는 다음과 같이 계산 지점의 경사각 $(\beta)$ 및 방위각 $(\phi)$ 의 함수로 표시된다.

$$
\lambda=\tan ^{-1}\left[\tan \beta \cos \left(\phi-\phi_{n}\right)\right]
$$

식 (6)과 (9)에서 계산되는 직달 성분과 산란 성분을 더하 여 지형 효과를 고려한 태양 에너지를 계산할 수 있다.

$$
B_{g l o}=B_{d i r} \cos \theta+B_{d i f}
$$

고해상도 및 초고해상도 태양 에너지는 $1 \mathrm{~km}$ 해상도의 태 양-기상자원지도의 시간별 수평면 태양 에너지 계산 결과를 이용하여 $10 \mathrm{~m}$ 해상도와 $1 \mathrm{~m}$ 해상도의 수치고도와 수치지면 자료를 적용하여 계산되며 연누적하여 비교한다.

\section{$2.21 \mathrm{~km}$ 해상도 태양-기상자원지도}

2009 년 개발된 태양-기상자원 지도는 $1 \mathrm{~km}$ 해상도 정지기 상위성의 구름량을 이용하여 GWNU 복사모델을 이용하여 계 산되었다(지준범 등, 2011; 이규태 등, 2011; 조일성 등, 2010) $(8,9,10)$. GWNU 모델은 위성에서 관측된 오존, 에어로솔 그리 고 수치모델의 가강수량을 이용하여 일차적으로 맑은 상태에 서 지표면에 도달하는 태양 에너지를 계산하였다. 태양 에너 지의 가장 큰 감쇠요인인 구름은 MTSAT-1R 자료를 이용하 였으며 가시채널 반사도와 지상관측 태양 에너지의 관계성을 이용하여 구름효과를 산출하였고 미리 계산된 맑은 상태의 태양 에너지에 곱하여 지표면 도달 태양 에너지를 계산하였 다. 태양-기상자원지도는 2009년부터 2011년까지의 자료를 이용하여 수평면과 지형면에 대하여 시간별로 계산되었으며 월누적 및 연누적 값으로 제공되고 있다(http://www.greenmap. go. $k r)^{(16)}$.

태양 에너지는 대기성분과 구름에 의한 감쇠가 중요한 요 소이나 천정각이 큰 계절과 오전, 오후에는 산악에 의하여 태 양 에너지의 차폐가 발생되며 경사면에서 받는 태양 에너지

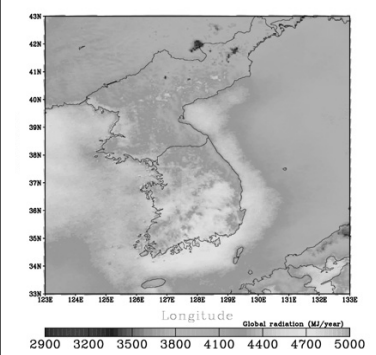

(a) Annual Solar radiation

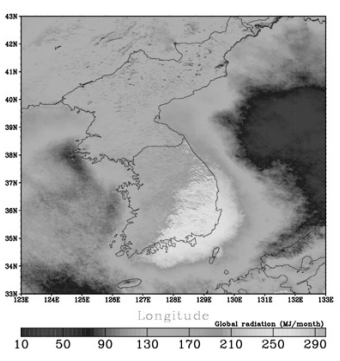

(c) December solar radiation

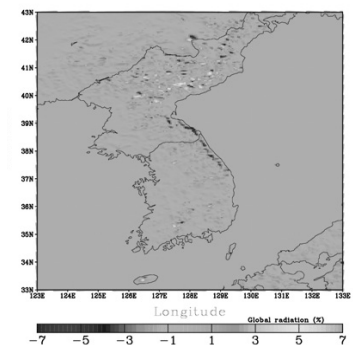

(b) Difference (\%)

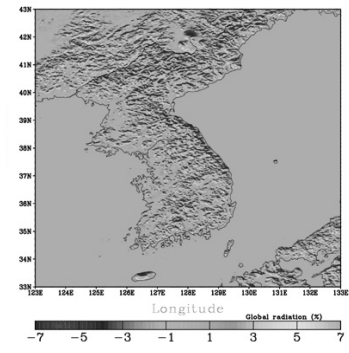

(d) Difference (\%)
Fig. 2 Annual and monthly accumulated surface solar radiations calculated by GWNU_Topo (a, MJ/year; c, MJ/month) with $1 \mathrm{~km}$ resolution and differences ( $b$ and $d, \%$ ) between GWNU_Topo. and GWNU_Hori. through 2010 to 2011

는 수평면과는 다르게 나타난다. $1 \mathrm{~km}$ 태양-기상자원지도는 $1 \mathrm{~km}$ 해상도의 지형을 고려하여 지형효과를 계산하였고 천정 각이 높은 12 월의 경우 수평면 태양 에너지와 비교하여 최대 $\pm 38 \%$ 의 차이를 보였다(Fig. $2(\mathrm{~d}))$. 연누적의 태양 에너지의 경우 산악이 복잡한 지역에서 $\pm 10 \%$ 이하의 차이를 보였다 (Fig. 2(b))(지준범 등, 2011) ${ }^{(8)}$.

\section{$2.310 \mathrm{~m}$ 해상도 DEM 자료}

$10 \mathrm{~m}$ 해상도 수치고도자료(DEM)는 국립지리원에서 제공 되며 Landsat 위성자료와 MODIS 자료를 이용하여 남한지역 에 대하여 구축되었다. Fig. 3은 $10 \mathrm{~m}$ 해상도 지형고도자료의 고도와 경사 및 향 그리고 천공률을 나타낸 것이다. 비교적 높은 산악지역에서 $50^{\circ}$ 이상의 경사각이 나타났으며 산악의 주변지역에서 천공률이 낮게 나타났다.

$10 \mathrm{~m}$ 해상도의 서울의 태양 에너지는 2.2 절의 $1 \mathrm{~km}$ 해상도 의 수평면 태양 에너지를 이용하여 2.1절의 지형효과를 적용 하여 계산하였다. 


\section{$2.41 \mathrm{~m}$ 해상도 $\mathrm{DSM}$ 자료}

$1 \mathrm{~m}$ 해상도의 수치지면자료(DSM)는 항공라이더를 이용하 여 관측된 고도자료를 GIS 툴을 이용하여 산출한 것이며 건 물의 고도 등 지표면 특성까지 상세하게 나타난다. Fig. 4는

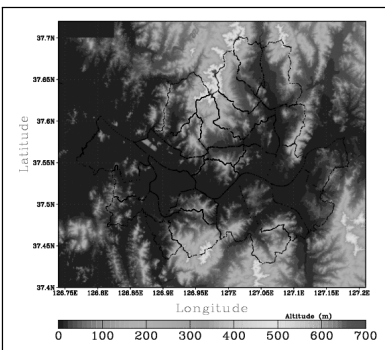

(a) Elevation (m)

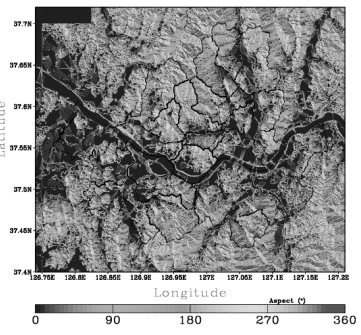

(c) Aspect ( ${ }^{\circ}$ )

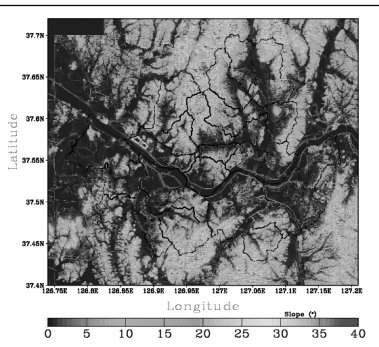

(b) Slope $\left({ }^{\circ}\right)$

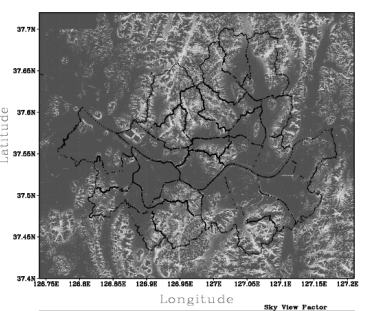

(d) Sky View Factor
Fig. 3 DEM(Digital Elevation Model), Slope, Aspect and Sky View Factor in Seoul

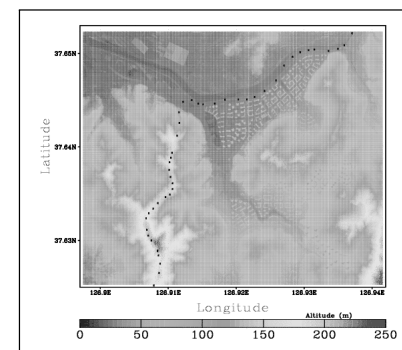

(a) Elevation (m)

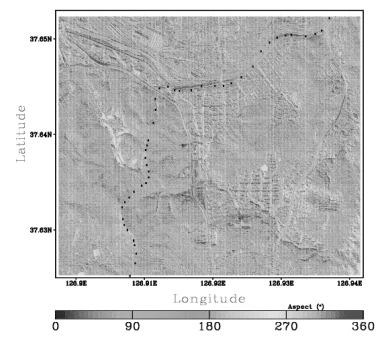

(c) Aspect ( $\left.{ }^{\circ}\right)$

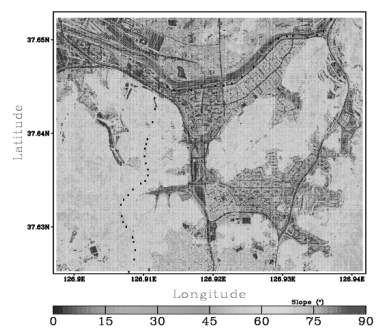

(b) Slope $\left({ }^{\circ}\right)$

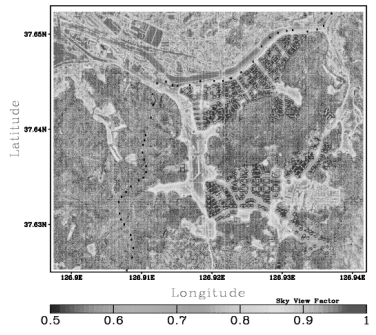

(d) Sky View Factor
Fig. 4 DEM(Digital Elevation Model), Slope, Aspect and Sky View Factor in Eunpyung-gu
서울 북서부의 은평 뉴타운 지역을 나타낸 것이며 주거지 개 발로 계획된 도시화지역으로 주변의 산과 하천이 위치하여 종합적인 도시와 산림지의 특성을 볼 수 있다. 산악지역은 경 사각이 높게 나타났으며 평지와 주거단지 주변에서는 천공률 이 높게 나타났다.

$1 \mathrm{~m}$ 해상도의 은평 뉴타운의 태양 에너지는 2.3 절의 $10 \mathrm{~m}$ 해상도 태양에너지 계산과 동일하게 2.2 절의 $1 \mathrm{~km}$ 해상도의 수평면 태양 에너지를 이용하여 2.1절의 지형효과를 적용하 여 계산하였다.

\section{3. 결과 및 토의}

지형효과가 고려된 지면의 태양 에너지는 2.2 의 매시간 $1 \mathrm{~km}$ 해상도의 태양-기상자원지도를 $10 \mathrm{~m}$ 또는 $1 \mathrm{~m}$ 해상도의 격자 로 내삽한 후, 2.3 과 2.4 의 지형특성자료(경사, 향, 천공률) 를 이용하여 2.1의 지형효과를 포함하여 계산하였다.

Fig. 5 는 $1 \mathrm{~km}$ 해상도에서 계산되어진 수평면태양 에너지 와 $10 \mathrm{~m}$ 해상도의 수치고도자료를 이용하여 계산된 태양 에 너지이다. 시간별로 계산된 태양 에너지는 연누적하여 $\mathrm{MJ}$ 단 위로 나타내었다.

Fig. 5(a)는 수평면의 연누적 태양 에너지의 분포이며 계 산 해상도가 $1 \mathrm{~km}$ 이기 때문에 해상도에 따른 뚜렷한 픽셀단 위로 나타난다. Fig. 5(b)는 지형의 영향을 고려하여 남향의 격자에서는 태양 에너지 증가가 뚜렷하게 나타나고 있다. 또 한 $10 \mathrm{~m}$ 해상도의 결과에서 서울 중심부를 중심으로 불연속 적인 자료들이 나타난다. 이러한 이유는 $1 \mathrm{~km}$ 해상도에서 계

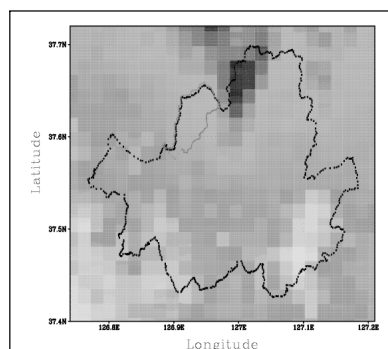

(a) $1 \mathrm{~km}$ resolution

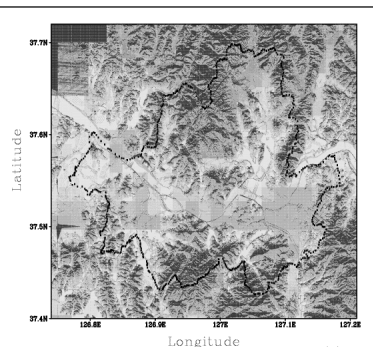

(b) $10 \mathrm{~m}$ resolution

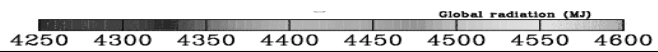

Fig. 5 Annual accumulated surface solar radiation (MJ/year) with $1 \mathrm{~km}$ and $10 \mathrm{~m}$ resolution. 


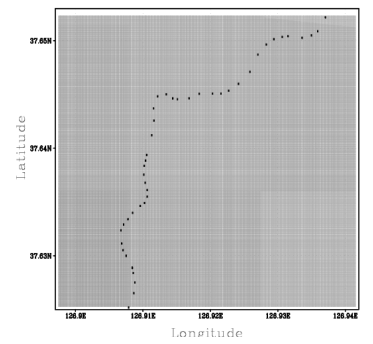

(a) $1 \mathrm{~km}$ resolution

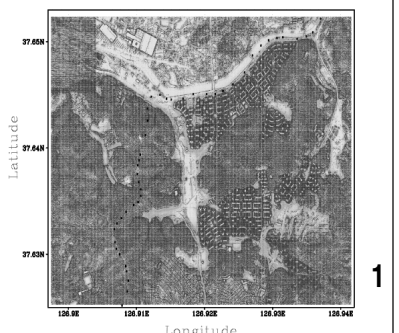

(b) $1 \mathrm{~m}$ resolution

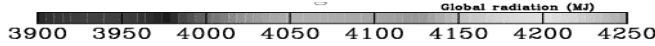

Fig. 6 Annual accumulated surface solar radiation (MJ/year) with $1 \mathrm{~km}$ and $1 \mathrm{~m}$ resolution

산된 태양 에너지에 의존적이기 때문이다. 그리고 남향의 지 역에서는 $1 \mathrm{~km}$ 해상도 태양 에너지와 비교하여 지표면 도달 태양 에너지가 평균 $\pm 120 \mathrm{MJ}$ 이상 차이가 있었고 산의 경사 면에서의 태양 에너지가 지형의 경사와 향에 따라 뚜렷이 증 가되거나 감소되는 것을 확인할 수 있다. 지형효과가 고려된 $10 \mathrm{~m}$ 해상도의 태양 에너지는 $1 \mathrm{~km}$ 해상도의 태양 에너지와 비교했을 때 최대 $\pm 21 \%$ 의 차이가 나타났다.

은평 뉴타운 지역의 $1 \mathrm{~m}$ 초고해상도 태양 에너지와 $1 \mathrm{~km}$ 해 상도의 수평면 태양 에너지는 Fig. 6에 나타내었다. 하천을 중심으로 낮은 평지에서 비교적 높게 나타났으며 산림지역에 서는 낮은 태양 에너지가 계산되었다. 또한 아파트가 밀집된 지역에서는 건물과 옥상의 모양에 따른 태양 에너지의 특성 이 그대로 반영되어 나타났다. $1 \mathrm{~km}$ 해상도의 태양-기상자원 지도의 결과는 약 6 픽셀의 값이 은평 뉴타운 지역을 덥고 있 어 유사한 픽셀간 유사한 값이 나타났다. $1 \mathrm{~m}$ 해상도의 태양 에너지는 $1 \mathrm{~km}$ 해상도의 태양 에너지와 비교하여 $\pm 250 \mathrm{MJ}$ 로 나타났고 평지와 산악지역의 편차가 일부지역을 제외하고는 뚜렷이 구분되어 나타났다. 그리고 지형효과가 고려된 $1 \mathrm{~m}$ 해 상도의 태양 에너지는 $1 \mathrm{~km}$ 해상도의 태양 에너지와 비교했 을 때 최대 $\pm 16 \%$ 의 차이가 나타났다.

$1 \mathrm{~km}$ 해상도의 태양 에너지는 한반도 전역에 대한 계산 결 과이고 $10 \mathrm{~m}$ 해상도와 $1 \mathrm{~m}$ 해상도의 태양 에너지는 서울과 은 평 뉴타운 지역에 한정되어 계산되었기 때문에 해상도별 태 양 에너지의 차이는 작게 나타난다. 그러나 해상도에 따른 지 형효과는 비교적 정확하게 계산될 수 있기 때문에 태양광 또 는 태양열 발전 등을 계획을 위해서는 현장조사를 선행하여 환경조사에 유용할 것으로 사료된다.

\section{4. 결 론}

$1 \mathrm{~km}$ 해상도의 태양-기상자원지도는 기상자료와 위성자료 를 이용하여 개발되었으며 한반도 전역에 대한 비교적 상세 한 태양 에너지의 활용을 평가할 수 있다. 그러나 지역 및 지 형의 특성에 따른 평가는 아직 미흡한 실정이다. 따라서 이 연구에서는 $1 \mathrm{~km}$ 해상도의 태양-기상자원지도 결과를 활용 하여 $10 \mathrm{~m}$ 해상도의 서울 수치고도자료와 $1 \mathrm{~m}$ 해상의 은평구 수치지면자료의 특성을 이용하여 고해상도 및 초고해상도 태 양 에너지를 계산하였다.

지형자료에 기반된 간단한 알고리즘이 적용되었으나 고해 상도 및 초고해상도 태양 에너지의 산출이 가능하다. 또한 지 형자료에 기반된 월별 또는 연누적 계산결과를 분석하면 연 간 태양 에너지의 잠재량 및 분포를 평가할 수 있다. 지역에 따른 태양 에너지는 산악 및 지형 그리고 건물들의 영향에 따 라 $10 \mathrm{~m}$ 서울의 경우 태양에너지는 최대 $\pm 21 \%$ 그리고 $1 \mathrm{~m}$ 은평 뉴타운의 경우는 최대 $\pm 16 \%$ 의 차이가 발생된다. 이러 한 차이는 본 연구의 태양 에너지의 계산이 해상도별로 지역 에 대해 한정하였기 때문에 작은 차이가 나타난 것이다.

따라서 태양 에너지 계산은 수치지표 및 수치고도자료를 이용한 지형효과가 비교적 정확하게 계산될 수 있으며 계산 된 태양 에너지의 결과는 태양광 또는 태양열 발전 등의 계획 을 위한 기초자료로 활용이 가능할 것으로 분석된다.

\section{후 기}

이 연구는 2013년 기상청 기상산업지원 및 활용기술 개발 사업(KMIPA 2013-12080)의 지원으로 수행되었습니다.

\section{References}

[1] Giuseppe, F. D., Tompkins, A. M. 2005, "Impact of cloud cover on solar radiative biases in deep convective regimes”, Journal of Atmospheric Sciences, Vol. 62, pp. 1989-2000.

[2] 정연진, 조희구, 김준, 김영준, 김유미, 2011, “구름에 의한 지표 일사량의 증가”, 대기지, Vol. 21, No. 2, pp. 131-142. 
[3] 김의화, 강승원, 김재언, 2011, "태양광발전시스템의 장기운 전에 의한 성능특성 분석”, 한국신재생에너지학회지, Vol. 7 , No. 2, pp. 28-35.

[4] 신은산, 여현구, 선우영, 2001, "서울지역에서 황사 에어로 졸의 통과량 추정 및 강화량 분포”, 대한위생학회지, Vol. 16, No. 1, pp. 9-17.

[5] 박승명, 문광주, 박종성, 김현재, 안중영, 김정수, 2012, “2009 년 서울지역 황사 및 고농도 미세먼지 사례 시 미세먼지의 화학성분 특성”, 한국대기환경학회지, Vol. 28, No. 3, pp. 282-293.

[6] 지준범, 이승우, 최영진, 이규태, 2012, "한반도 태양에너지 연구를 위한 일사량 자료의 TMY 구축”, 한국신재생에너지학 회지, Vol. 8, No. 2, pp. 14-23.

[7] 국립기상연구소, 2011, "녹색성장 기상지원기술 개발(II)", 국립기상연구소 응용기상연구과, 11-1360395-00075-10, p. 588

[8] 지준범, 조일성, 이규태, 최영진, 2011, "지형효과를 고려한 지표면 태양광 분포”, 지구과학회지, Vol. 32, pp. 190-199.

[9] 이규태, 조일성, 지준범, 최영진, 2011, "한반도에서 해상도 변화에 따른 지표면 일사량의 시공간 분포”, 한국신재생에너
지학회지, Vol. 7, No. 1, pp. 22-28.

[10] 조일성, 지준범, 이원학, 이규태, 최영진, 2010, “복사 모델 에 의한 남한의 지표면 태양광 분포”, 한국기후변화학회지, Vol. 1, No. 2, pp. 147-161.

[11] 이채연, 안승만, 김규랑, 최영진, Dieter Scherer, 2012, "상 세 공간정보를 활용한 국지기온 분석 개선”, 한국지리정보학 회지, Vol. 15, No. 1, pp. 144-158.

[12] Lai, Y. J., Chou, M. D., Lin, P. H., 2009, "Parameterization of topographic effect on surface solar radiation”, Journal of Geophysical Research, 115, D01104, doi:10.1029/ 2009JD012305.

[13] Zhou, Q., Liu, X. 2004, "Analysis of errors of derived slope and aspect related to DEM data properties", Computers \& Geosciences, Vol. 30, pp. 369-378.

[14] Horn, B. K. P. 1981, "Hill shading and the reflectance map”, Proceedings of IEEE, Vol. 69, No. 1, pp. 14-47.

[15] Kondratyev, J., 1969, "Radiation in the Atmospheric", Academic Press, USA, p. 912

[16] 기상자원지도 홈페이지: www.greenmap.go.kr, 검색일(2013. 6.14.) 


\section{지 준 범}

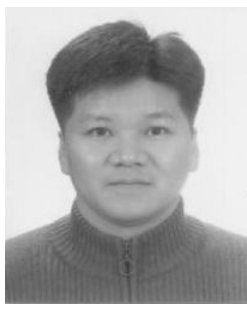

1999년 강릉대학교 대기환경과학과 이학사 2001년 강릉대학교 대기환경과학과 이학석사 2008년 강릉대학교 대기환경과학과 이학박사

현재 (재)기상기술개발원 차세대도시농림융합기상사업단 선임연구원 (E-mail；rokmcjjb717@gmail.com)

\section{이 채 연}

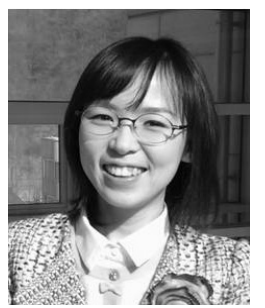

2002년 서울여자대학교 환경학화 이학사 2005년 한양대학교 환경공학과 대기공학전공 공학석사

현재 기상청 국립기상연구소 응용기상연구과 연구원 (E-mail ; prpr2222@korea.kr)

\section{김 규 랑}

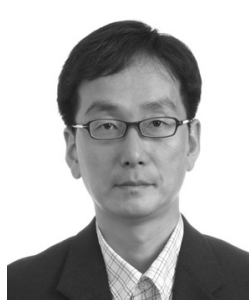

1992년 서울대학교 농생물학과 농학사 1995년 서울대학교 농생물학과 식물병리전공 농학석사

2001년 서울대학교 농생물학과 식물병리전공 농학박사

현재 기상청 국립기상연구소 응용기상연구과 연구관

(E-mail : krk9@kma.go.kr)

\section{조 일 성}

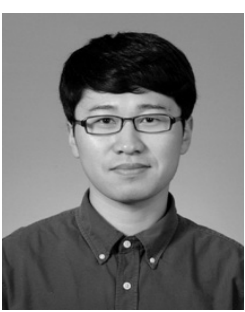

2008년 강릉대학교 대기환경과학과 이학사 2010년 강릉원주대학교 대기환경과학과 이학석사 2013년 강릉원주대학교 대기환경과학과 박사수료

현재 강릉원주대학교 자연과학연구소 전임연구원

(E-mail；zoilsung@sky.gwnu.ac.kr)

\section{최 영 진}

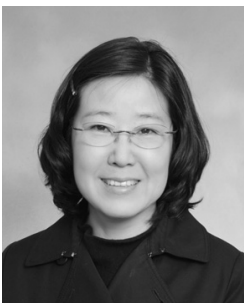

1981년 연세대학교 천문기상학과 이학사 1984년 연세대학교 대기과학과 이학석사 2003년 연세대학교 대기과학과 이학박사

현재 기상청 국립기상연구소 지구환경시스템연구과 과장

(E-mail ; yjchoikma@korea.kr)

\section{이 규 태}

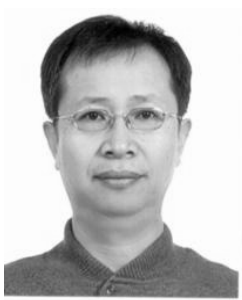

1981년 연세대학교 대기과학과 이학사 1983년 연세대학교 대기과학과 이학석사 1992년 연세대학교 대기과학과 이학박사

현재 강릉원주대학교 대기환경과학과 교수

(E-mail ; ktlee@gwnu.ac.kr) 